\title{
Correction: History of drug use in allogeneic hematopoietic cell transplant recipients
}

Mouhamed Yazan Abou-Ismail • Gayathri Ravi • Pingfu Fu D - Shufen Cao - Sowjanya Vuyyala • Paolo Caimi • Merle Kolk • Nicole Ferrari • Kirsten Boughan • Brenda Cooper (D) - Molly Gallogly • Folashade Otegbeye (D) Benjamin Tomlinson - Marcos de Lima (D) - Leland Metheny $($ D

Published online: 21 October 2020

(c) The Author(s), under exclusive licence to Springer Nature Limited 2020

Correction to: Bone Marrow Transplantation

https://doi.org/10.1038/s41409-020-01058-z

The original version of this Article contained an error in the presentation of the author name for Dr. Abou-Ismail.
The first name was incorrectly published as Mouhamed instead of Mouhamed Yazan and the surname as Yazan Abou-Ismail instead of Abou-Ismail. This has now been corrected in both the PDF and HTML versions of the Article. 